\title{
PRICE TRANSMISSION OF SKIM MILK POWDER IN INDONESIA: DO SKIM MILK POWDER IMPORT PRICES FOLLOW THE PRICES IN NEW ZEALAND?
}

\author{
Venty Fitriany Nurunisa ${ }^{1)}$, Bonar Marulitua Sinaga ${ }^{2)}$, Ratna Winandi ${ }^{3)}$ \\ and Bernhard Brümmer) \\ ${ }^{1,3)}$ Magister Sains Agribisnis, Fakultas Ekonomi dan Manajemen, Institut Pertanian Bogor \\ 2) Program Studi Ekonomi Pertanian, Fakultas Ekonomi dan Manajemen, \\ Institut Pertanian Bogor \\ ${ }^{4)}$ Department of Agricultural Economics and Rural Development, \\ Georg August University of Goettingen, Germany \\ ${ }^{1)}$ venty.fitriany.nurunisa@gmail.com
}

\begin{abstract}
The objectives of this research are i) to examine New Zealand's dairy sector and ii) to analyze the market integration and price transmission of Skim Milk Powder (SMP) of New Zealand and Indonesian market. The methods used are Augmented Dickey Fuller test, Johansen Cointegration test, and Vector Error Correction Model. The result indicates: 1) as trade partner, New Zealand is powerful due to its status as the largest dairy producer worldwide; therefore, Indonesia has less bargaining power and 2) The SMP market of both countries are integrated. The coefficient of long run equation variable indicates that every 10 percent changes of one market, the imported SMP price will adjust 10.97 percent, while the exported SMP price will adjust 9.12 percent. The loading vector coefficient indicates that Indonesia is the only party adjusting to long run disequilibrium. Policies to minimize the risks includes: i) buffer budget, ii) alternative suppliers and iii) futures trade.
\end{abstract}

Keyword(s): ADF test, Johansen test, market integration, price transmission, skim Milk Powder market, VECM.

\begin{abstract}
ABSTRAK
Penelitian ini bertujuan untuk i) menganalisa kondisi industri susu Selandia Baru dan ii) menganalisa integrasi pasar dan transmisi harga susu skim bubuk di pasar Selandia Baru dan Indonesia. Metode yang digunakan adalah uji Augmented Dickey Fuller, uji Kointegrasi Johansen, dan Vector Error Correction Model. Hasil penelitian menunjukkan bahwa: 1) sebagai mitra dagang, Selandia Baru lebih berdaya karena statusnya sebagai eksporter produk produk susu terbesar di dunia; sehingga posisi tawar Indonesia lebih rendah dan 2) Pasar susu skim bubuk di kedua negara memiliki terintegrasi. Koefisien dari variabel persamaan jangka panjang menunjukkan bahwa setiap 10 persen perubahan yang terjadi di satu pasar, harga susu skim bubuk impor akan menyesuaikan sebesar 10,97 persen, sementara harga susu skim bubuk ekspor akan menyesuaikan sebesar 9,12 persen. Berdasarkan nilai loading vector, Indonesia adalah satu-satunya pihak yang menyesuaikan diri dengan disekuilibrium di jangka panjang. Beberapa strategi kebijakan yang dapat dilakukan untuk mengurangi risiko adalah: i) buffer budget ii) pemasok alternatif dan iii) perdagangan komoditi berjangka.
\end{abstract}

Kata Kunci : Integasi pasar, pasar susu skim bubuk, transmisi harga, uji ADF, uji Kointegrasi Johansen, VECM 


\section{INTRODUCTION}

Trade liberalization is a concept where two countries or more agree to reduce the trade borders through the settlement of lower tariff and/or nontariff barriers or even totally erase them from the trade (Ministry of Trade, 2014). The trade liberalization agreement is expected to give benefits for the countries involved either in a form of trade creation or trade diversion (Ministry of Trade, 2014). The implementation of trade liberalization forces the countries to improve the competitiveness of their local industry. One of the most important strategies is that countries should ensure that the market is well functioned, which indicates a condition of a competitive market.

A well-functioned market leads a country to have a better opportunity in achieving their welfare objectives. A well functioned market is also reflecting a competitive price behavior among traders (Fackler \& Goodwin, 2001). Competitive price behavior explains the situation of a fully transmitted price between market. It implies that any changes in one market at any point in time, will influence the condition of other markets.

Indonesia is a country that the economy is now growing. Known as an agricultural based country, the GDP from the agricultural sector in Indonesia has contributed approximately $15 \%$ to the national GDP in the year 2013. The implementation of trade liberalization in Indonesia has made the government sets specific trade regulations to monitor any effects brought by the trade liberalization. Specifically, Abdulai (2006) stated that factors like infrastructure, including the quality of the physical infrastructure, becomes an important factor which influence the amount of transaction costs. Poor infrastructure implies to poor distribution of market information. This may hinder the achievement of a full price transmission (Abdulai, 2006).

Table 1. Import of Primary Goods in Indonesia (2013)

\begin{tabular}{lcccl}
\hline Commodities & $\begin{array}{c}\text { Value } \\
\text { (Million US\$) }\end{array}$ & $\begin{array}{c}\text { Volume } \\
\text { (Million Kgs) }\end{array}$ & $\begin{array}{c}\text { Unit Value } \\
\text { (US \$/Kg) }\end{array}$ & Origin Country \\
\hline Wheat Seeds & $1.460,00$ & $3.900,00$ & 0,37 & Thailand \\
Sugar Cane & $1.040,00$ & $1.980,00$ & 0,53 & India \\
Soybean & 670,46 & $1.090,00$ & 0,62 & USA \\
Milk & 459,36 & 123,25 & 3,73 & New Zealand \\
Maize & 275,35 & 897,35 & 0,31 & Sri Lanka \\
Garlic & 236,06 & 291,45 & 0,81 & Thailand \\
Cattle & 151,69 & 55,13 & 2,75 & Australia \\
Rice & 137,39 & 266,88 & 0,51 & Thailand \\
Meat & 110,40 & 22,70 & 4,86 & Australia \\
Salt & 55,90 & $1.200,00$ & 0,05 & Malaysia \\
Butter & 51,91 & 11,94 & 4,35 & Australia \\
Wheat & 40,89 & 92,75 & 0,44 & New Zealand \\
Cacao & 40,70 & 16,32 & 2,49 & India \\
Cooking Oil & 36,90 & 37,64 & 0,98 & New Zealand \\
\hline
\end{tabular}

Source: Ministry of Trade (2013) 
Trade liberalization forces local industries in a country to improve their export performance. However, on the other side, trade liberalization is also encouraging the import activities of the countries. Statistics show that the amount of imported primary goods of Indonesian people is quite large. Some of them even indicate an import dependency. Significant import amounts were shown by some commodities, i.e. milk, which imported almost $70 \%$ of the total national demand, the other are sugar (30\%), salt $(50 \%)$, soybean $(70 \%)$, meat $(30 \%)$ and wheat which imported for nearly $100 \%$ of the total national demand.

The Indonesian Ministry of Trade specifically monitors market and the price of those primary goods. Table 1 is taken from the Ministry of Trade (2013). It shows the list of imported primary goods in Indonesia during year 2013. The most valuable and voluminous imported commodities are wheat seeds (Thailand), sugar cane (India), and soybean (USA). However, based on the unit value, meat (4,86 US \$/Kg), butter (4,35 US \$/Kg) and milk $(3,73$ US $\$ / \mathrm{Kg})$ are considered as the most expensive among all of the products. These livestock products are routinely consumed and largely imported by the Indonesian. In this case, the availability and price stability of those goods are important to be concerned. Any shocks to the availability and prices may initiate a socioeconomic instability, or even trigger political dynamic.

The Indonesian government classified some commodities as a strategic commodity. The classifications of strategic commodity are based on several considerations, i.e. the economic value of the commodity, potency of business development and a greater public involvement in the commodity development. Originated from the livestock subsector,

Tabel 2. Import Volume and Value of Milk and Dairy Products Year 2007-2011

\begin{tabular}{lcccl}
\hline Commodities & $\begin{array}{c}\text { Value } \\
\text { (Million US\$) }\end{array}$ & $\begin{array}{c}\text { Volume } \\
\text { (Million Kgs) }\end{array}$ & $\begin{array}{c}\text { Unit Value } \\
\text { (US \$/Kg) }\end{array}$ & Origin Country \\
\hline Wheat Seeds & $1.460,00$ & $3.900,00$ & 0,37 & Thailand \\
Sugar Cane & $1.040,00$ & $1.980,00$ & 0,53 & India \\
Soybean & 670,46 & $1.090,00$ & 0,62 & USA \\
Milk & 459,36 & 123,25 & 3,73 & New Zealand \\
Maize & 275,35 & 897,35 & 0,31 & Sri Lanka \\
Garlic & 236,06 & 291,45 & 0,81 & Thailand \\
Cattle & 151,69 & 55,13 & 2,75 & Australia \\
Rice & 137,39 & 266,88 & 0,51 & Thailand \\
Meat & 110,40 & 22,70 & 4,86 & Australia \\
Salt & 55,90 & $1.200,00$ & 0,05 & Malaysia \\
Butter & 51,91 & 11,94 & 4,35 & Australia \\
Wheat & 40,89 & 92,75 & 0,44 & New Zealand \\
Cacao & 40,70 & 16,32 & 2,49 & India \\
Cooking Oil & 36,90 & 37,64 & 0,98 & New Zealand \\
\hline BMP : Buttermilk Powder & & & \\
WMP $:$ Whole Milk Powder & & & \\
SMP $:$ Skim Milk Powder & & & \\
Source : Asnawi (2012) & & &
\end{tabular}


meat and milk are classified as a strategic commodity. Even the production and consumption of these two commodities is relatively still low. However, the dairy agribusiness in Indonesia has a bigger potency to be developed as a growing sector. The dairy agribusiness sector is supported by numbers of farmers and institutions within. Supported by the condition of the geographical, ecological and also the availability of grasslands in several areas, Indonesia has the opportunity to develop its dairy agribusiness into a more advanced agricultural system.

However, the availability of abundant natural resources not necessary put dairy business in Indonesia as a promising sector yet. Even naturally, dairy farms in Indonesia have already had the comparative advantage (Baga \& Yanuar, 2009), however, this sector still needs a more advanced management to improve its competitive advantage. Today, a poor performance of Indonesia's dairy sector appears on a low number of milk production, which only reaches $30 \%$ of the total national demand.

Fulfilling the national milk need, Indonesia imports milk from several partner countries. Indonesia has become a net importer of milk products for years. Indonesia imports about $70 \%$ of the total national demand. The most imported milk products are the Skim Milk Powder (SMP) or the nonfat milk powder. SMP is used as a mixture ingredient by the Indonesia's dairy companies. Skim Milk Powder is basically needed as the main ingredient in Powder Milk, Sweetened Condensed Milk and other milk productions.
Table 2 explains the import activity of some dairy products in Indonesia. As mentioned previously, Skim Milk Powder is the most imported milk products from Indonesia. At 2007, the import of Skim Milk Powder reached $30,5 \%$ from the total of imported dairy product. This share is rising over time, in 2010 imported SMP became 43,7\%, which means it increase about 13,2\% from the year 2007. Moreover, as a net importer, Indonesia mainly imported milk from New Zealand, Australia and the USA. Indonesia does not have a power to influence the international price. The international milk price is generally influenced by the big players, i.e. New Zealand, Australia and European Union.

On the demand side, the consumption level of milk in Indonesia is relatively still low. The average milk consumption in Indonesia is about 10,47 $\mathrm{kg}$ /capita/year, or about 0,171 liters/ capita/day. This number is lower than the average milk consumption of other ASEAN countries such as the Philippines (20 kg/capita/year), Malaysia (20 kg/ capita/year), Thailand (20-25 kg/ capita/year) and Singapore (32 kg/ capita/year) (Ministry of Industry, 2009). The low level of Indonesia's milk consumption is expected to be influenced by two factors. First, it is caused by the milk price which is relatively much higher than the other calcium source. Second, it is also influenced by the fact that milk drinking is not yet a habit for most of Indonesian people.

Specifically, in the Oceania area, New Zealand is the biggest producer and exporter of dairy products. Indonesia is 
one of a milk importer from New Zealand. New Zealand became the biggest milk exporter in the world with a $28,8 \%$ market share in 2012. The Ministry of Primary Industry of New Zealand (2014) stated that the country is the world's largest dairy and sheep meats exporter worldwide. Dairy sector has contributed the largest share from this country's total export. Specifically, in Skim Milk Powder, New Zealand has supplied approximately 33,6\% of Indonesia's needs. But this amount is only $4,1 \%$ of New Zealand's Skim Milk Powder export. Indonesia's import value of skimmed milk powder from New Zealand is reflected on Figure 1. It can bee seen that the import value has a very rigid fluctuation, however it shows a rising trend over the last years (ITC, 2014).

In conclusion, milk import by Indonesia is just the small part of the whole New Zealand's exports. In a case of Skim Milk Powder, any changes in Indonesia's demand for this good, might not significantly influence the New Zealand's Skim Milk Powder export. Otherwise, a meaningful milk supply from New Zealand to Indonesia might be a reason of Indonesia's import dependency. Changes or shocks in New Zealand's dairy sector apparently might affect the Indonesian market because of the large contribution of New Zealand. Often, the shocks are also influencing the local activity, especially in the local milk price determination process.

Generally, the domestic milk prices have a similar movement with the international milk prices, which driven by the price of New Zealand's prices. In the case of Skim Milk Powder, the same direction of price movement between international milk price and domestic price can be seen from the Figure 2 . Figure 2 explains the price movement of Skim Milk Powder's price from New

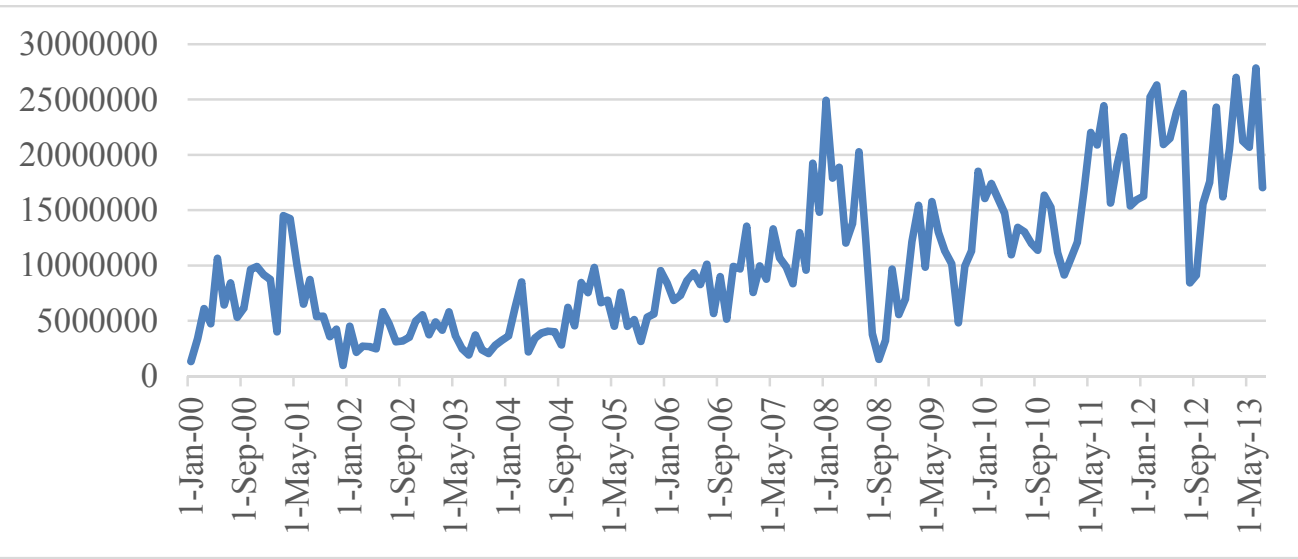

Source: ITC (2014)

Figure 1. Indonesia's Import Value of Skim Milk Powder from New Zealand in USD (2000-2013) 
Zealand to Indonesia (blue line) and the Skim Milk Powder's price in Indonesia which imported from New Zealand. The similar direction of both prices in Figure 2 indicates the existence of market integration of Skim Milk Powder between New Zealand's market and Indonesia's. However, the graph has not explained the cointegration relationship between those prices .

For more than one decade, Indonesia has built agreements with some partner countries in regard to implementation of free trade agreement. ASEAN Free Trade Agreement (AFTA), China-ASEAN Free Trade Area (CAFTA) and ASEANAustralia-New Zealand Free Trade Area (AANZFTA) are some of the committed agreements by Indonesia and the other partner countries. The implementation of trade liberalization through Free Trade Agreement are committed in regard to create a better trade circulation between countries and also to build the more attractive business atmosphere in every country. The FTA automatically fades the country's border and barriers, including the trade relationship between Indonesia and New Zealand which now is bounded by the AANZFTA.

A comprehensive analysis of price transmission and market integration is needed since Indonesia has no power to influence the price and international market. This might not be good since the price risk is relatively higher in Indonesia. Besides, the market integration study examines also how far the role of FTA has worked with regard to create a better market mechanism.

At last, the trade activity between New Zealand and Indonesia in Skim Milk Powder specifically left some market issues which are interesting to be analyzed. Awareness of international milk market and trade should be built up even more, since Indonesia is indicating an import dependent of Skim Milk Powder. Therefore, the objectives of this study are: i) to analyze a current condition of inter trade relationship between Indonesia and New Zealand, and ii) to

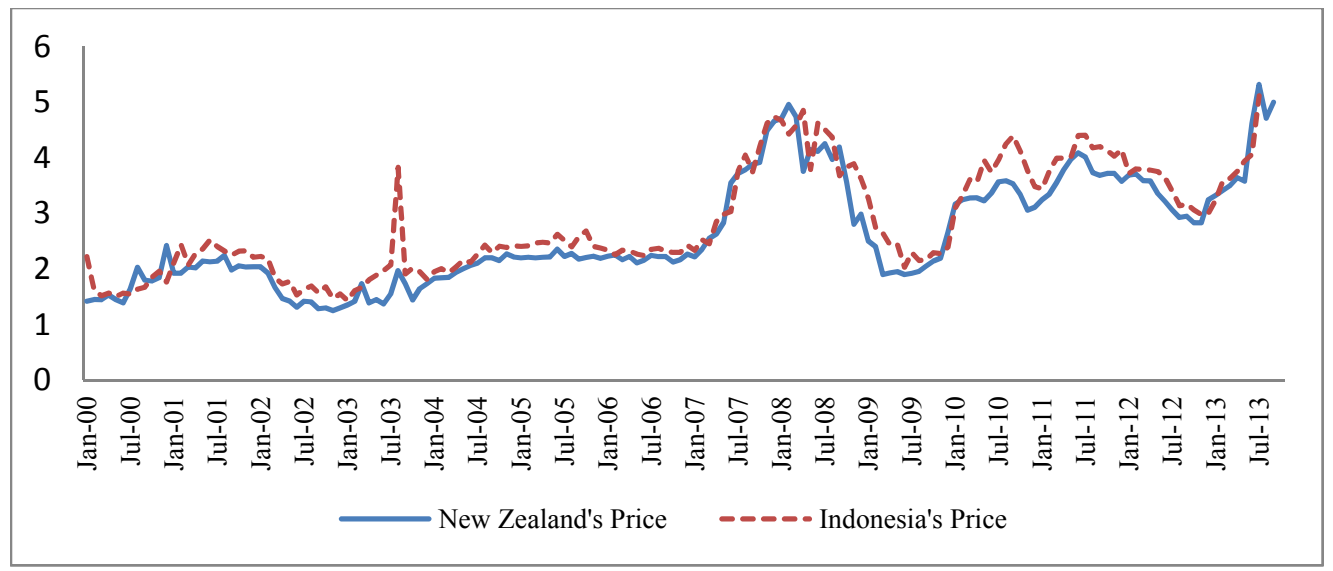

Source: ITC (2014)

Figure 2. Comparison between New Zealand's Skim Milk Powder Prices with Indonesia's Prices (US\$/Kg) 
analyze the market integration and price transmission of Skim Milk Powder in Indonesia, do Skim Milk Powder prices in Indonesia follow the prices in New Zealand.

\section{FRAMEWORK}

\section{Theoritical Framework}

In this part, the framework of the study will be provided to understand how the market works does theoretically. Started by price, it is important to be noticed that price is an important instrument which widely used in many policy implication studies. In international trade studies, price analysis may broaden the stakeholders a better understanding with regard to market and trade issue. Price transmission study, specifically observes the impact of changes or dynamic situation which occur in one market to another related market. The understanding of price movement and transmission will give benefits to companies, government and other stakeholders have a better knowledge and information on how shock in one powerful market will give impact to the others. In a case of milk price transmission between New Zealand and Indonesia, several theories on prices and market integration are suitable to underline the studies.

\section{Concept of Market Integration}

Market integration is a concept where prices in markets which are separated spatially or exist on a different level of the supply chain are stirred by the supply and demand mechanism. One can be indicated as market integration is the movement of goods, services and production factors among markets.

Based on the flow of the goods, market integration is divided into vertical and spatial market integration. Vertical market integration is the integration between markets in different level of the supply chain. While spatial or horizontal market integration is the integration between spatially separated markets.

The marketing system is found to be efficient if the previous prices of the market are used accurately in the current price determination. Ravallion (1986) assumed that the current condition of the economy is a reaction of the past system, therefore in the price transmission process the lag determination from the dependent variables are important to be considered into the model. This approach is also provides the method to analyze the existence of market power among traders.

\section{Law of One Price}

The Law of One Price is a fundamental idea in modern and classical models of international trade (Fackler and Goodwin, 2001). Law of One Price holds the assumption of commodity transfer between markets should be in the same price in all regions. Consider the existence of transfer costs c. Thus, it would be formulated as follows:

$$
\mathrm{p}_{1 \mathrm{t}}=\mathrm{p}_{2 \mathrm{t}}+\mathrm{c}
$$

where $p_{i t}$ is price of commodity $i$ and c is transfer cost in some points of time. On his book 'Principles of Economics', Marshall (1890) pointed out that the perfect situation where Law of One Price 
holds is when it is about reflecting the perfect market system, where the tendency of paying the same cost for the same good at the same time in different markets do exists.

However, the full price transmission as the Law of One Price (LOP) has been formulated is nearly an extreme case, which might be unlikely to occur, especially in a short run. In the short run, there might be some factors which could hamper the LOP to occur. The equation below formulates the condition if there is no full price transmission:

$\mathrm{p}_{1 \mathrm{t}}=\mathrm{p}_{2 \mathrm{t}}+\lambda \mathrm{c}$

where $\lambda$ is a 0 - 1 Constanta. Equation (ii) explains the condition where there is a weak Law of One Price. The difference between the short run and the long run is important to analyze the extent issue of which markets are integrated in the long run. In the short run, price transmission can be also influenced by policies, market power, and also different response to price as the price in the input changes (Rapsomanikis, Hallam, Conforti, 2003).

\section{The Model of Spatial Equilibrium}

Through the integration of excess supply market and excess demand market, Tomek \& Robinson (1990) introduced a model which generates the excess supply and demand into the expected price and quantity of tradable goods from each market.

The demand and supply curves are used to analyze the potential deficit or surplus which is gained from the trade activity. Potential surplus region (A) and potential deficit region (B) can help us to illustrate the general principles involved in developing interregional trade models. In the absence of trade, the demand and supply in each region will be in $\mathrm{Pa}$ for Region $\mathrm{A}$, and $\mathrm{Pb}$ for Region $\mathrm{B}$. At price above $\mathrm{Pa}$ some product would be available to be traded to another region, while in Region B, import would be required to meet the demand if the prices stand below $\mathrm{Pb}$. The excess supply and demand curves then can be determined as it shown on the third diagram on the right part. The intersect point in the third diagram illustrate trade prices. If there is no transfer cost and other cost between the trade activity of market $A$ and market $\mathrm{B}$, the equilibrium point of both market is Q2 for the quantity and $\mathrm{P}^{*}$ for the price. However, the equilibrium quantity will decrease along with the increase of transfer cost (TC). If the transfer cost (TC) is getting higher than $\mathrm{Pb}-\mathrm{Pa}$, there will be no transaction between market $\mathrm{A}$ and $\mathrm{B}$. The existence of tariff and nontariff barriers will increase the transfer cost. Figure 3 explains how is the price mechanism reaches equilibrium.

\section{The Concept of Price Transmission}

Price transmission is a process of price changes in one market will be transmitted and being responded by other market, either vertically (transmitted in different level of the supply chain), horizontally (transmitted in the spatially separated area) or cross product (price transmission with different commodity but still on the same production line) (Meyer \& Taubadel, 2002). Price transmission. Price transmission in 


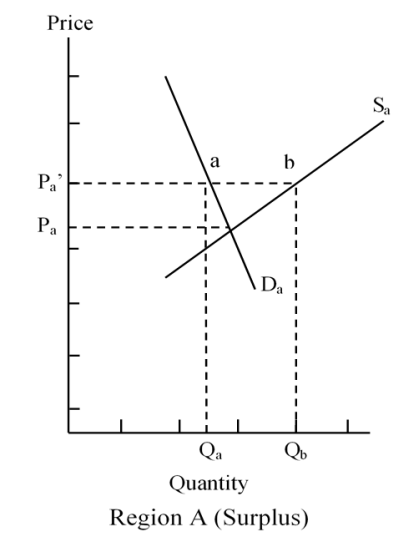

Source: Tomek \& Robinson (1990)
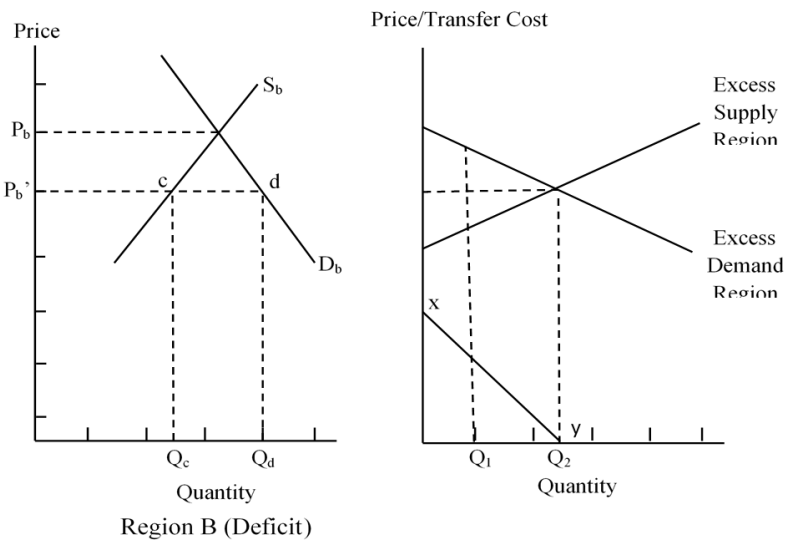

Figure 3. Trade Curve of Surplus Potential Area and Deficit Potential Area

markets causes the integration in the market.

Specifically, in the milk case between New Zealand and Indonesia, the horizontal price transmission becomes an important issue to be analyzed. It becomes more important since the applied trade liberalization causes the trade barriers between both countries are getting bias.

\section{Asymmetric Price Transmission}

Previously, it mentioned that a weak LOP will hamper a full price transmission in the short run. However, the role of arbitrage could fix that condition and returned it into normal in the long run. The difference between price transmission in the short run and in the long run, also the speed of price adjustment from disequilibrium to equilibrium condition are important information, therefore the degree of market integration in the short run can be generated (Rapsomanikis, Hallam, Conforti, 2003).
The price transmission process often occurs asymmetrically. Meyer \& Taubadel (2002) mentioned that asymmetric price transmission might occur since there are different responses in a way of transmission magnitude and/or speed of transmission. The existence of market power in the commodity market might cause the asymmetric price transmission to occur either positive or negatively. Market power is a condition of one party in the market, which influence stronger than the other parties. The condition allows the company or country with market power to have a greater control in prices, demand, flow of goods, marketing function and other parties behavior.

\section{Conceptual Framework}

The open trade concept supports the market integration between the world market and domestic market to occur. Trade liberalization agreements which have applied in some countries widen the opportunity of collaborating internatio- 
nally. Specifically the Australia ASEAN New Zealand Free Trade Agreements (AANZFTA) has become a commitment from each participating country, especially New Zealand and Indonesia support the global free trade. The implication of this agreement is that the trade barriers in each participant will be deleted gradually in order to support the improvement of competitiveness of each country.

This condition brings benefits for some Indonesia's strategic export commodities. However, on the other side, the increase of import goods should be also concerned by the government. Milk import which has reached about $70 \%$ of the total national demand should also be anticipated. As a milk net importer, Indonesia is facing a greater price risk, where New Zealand as the main milk exporter to Indonesia is found to give more fluctuation in milk export price to Indonesia rather than to the world market. Skim Milk Powder, which is the largest Indonesia's imported milk from New Zealand is currently essential since the availability is needed by most of Indonesian milk processing companies.

The Indonesia's import dependence to New Zealand's dairy products and the applications of free trade agreements which bound these two countries, have made the study regarding to international price and trade is important to be analyzed. The condition of milk trade today has brought a big question. Is there any evidence of market integration between Indonesia and New Zealand in a case of Skim Milk Powder? Are there any indications of the market power existence performed in New Zealand, since the price control is maintained by this country? Therefore, to answer those questions, study of price transmission and market integration will be performed.

\section{RESEARCH METHOD}

\section{Data and Instruments}

The price transmission analysis is conducted by using the monthly milk price data both from New Zealand and Indonesia. The monthly milk data from Indonesia were collected from Ministry of Trade Republic of Indonesia (www.kemendag.go.id), Ministry of Industry Republic of Indonesia (www.kemenperin.go.id) and Center Board of Statistics (www.bps.go.id). Meanwhile, the monthly milk data from New Zealand were collected from the International Trade Centre's website (www.trademap.org), Global Trade Information Services (www.gtis.com), and the CEIC data (www.ceicdata.com). The first objective, analysis of inter trade relationship between Indonesia and New Zealand is being analyzed descriptively. Meanwhile, the second objective, the price transmission analysis is being proceed through the following steps: i) test of unit root to check the stationary of the variables, ii) test of cointegration and iii) the construction of VEC Model.

Specifically, the analysis processed by using the monthly export and import volume and value data of Skim Milk Powder (HS 040221 and HS 040210) and then converted into price data by dividing the volume of Skim Milk Powder by the value each year. Skim Milk Powder is the 
most traded milk products between Indonesia and New Zealand.

Indonesia has imported Skim Milk Powder mostly for industrial purposes. The demand of imported skimmed milk is getting higher over time due to the increase of milk processing capacity in Indonesia. All Skim Milk Powder data in this study were transformed into IDR by using the real exchange rate for each period. Further, the whole data was also transformed into $1 n$, to reduce a possibility of bad calculation which is caused by the extreme fluctuation of economic data. The data used are the export and import data of Skim Milk Powder from Indonesia and New Zealand from January 2000 until July 2013, or about 163 observations.

\section{Data Processing}

The classical regression model requires the sequences of stationary variables in the observation (Enders, 2010). A stationary variable is reflecting a finite variance and autocovariance which also independent of time (Verbeek, 2012). The existences of non-stationary variables on the observation may lead to the spurious regression to occur. Spurious regression has a high $\mathrm{R} 2$ and $\mathrm{t}$-statistics that appear as significant, but the results tend to not having any economic meaning (Enders, 2010). Verbeek (2012) strengthens that spurious regression is leading the result into a misleading estimation and statistics results. Nevertheless, it will be an exclusion if there is some linear combination within the estimations which indicates the cointegration relationship in the long run. There are several steps to examine cases of nonstationary variables, they are briefly explained as follows:

\section{Unit Root Test}

The unit root test is an examination to check whether the variables are stationary or non-stationary. Augmented Dickey Fuller (ADF) test is one of a common approaches to examine the problem of non-stationary variables. This test considers the null hypothesis $y_{t}$ is non-stationary, under the alternative hypothesis $y_{t}$ that is stationary. If both variables are stationary, it is not necessary to go through any further step, since the standard time-series methods are adequate to stationary variables. Mathematically, the equation of Augmented Dickey Fuller can be composed as follows:

$\Delta Y_{t}=\alpha_{0}+\alpha_{1} T+\delta_{t} Y_{t-i}+\sum \beta_{i} \Delta Y_{t-i}+\varepsilon_{t}$

with $\varepsilon \sim \operatorname{IID}\left(0, \sigma^{2}\right)$

where $\Delta$ is reflecting the first difference of $\Delta \mathrm{Y}_{-} \mathrm{t}=\mathrm{Y}_{-} \mathrm{t}-\mathrm{Y}_{-}(\mathrm{t}-1)$. If the null hypothesis of $|\delta \mathrm{t}|=0$ is rejected, that is means that variables are stationary or do not contain any unit root. However the hypothesis could be also written as follows:

$H_{0}: \delta=0$ against $H_{1}: \delta<0$

\section{Cointegration Test}

Johansen test is used widely as an approach to test the cointegration relationship between non-stationary variables. Johansen test estimates the test through rank. The test procedure allows 
the existence of more than one cointegration relationship. Maximum Likelihood (ML) method approach is used to overcome the case of multivariate variable combinations in Johansen test. The multivariate variable combination will lead the estimations to have a wellbehaved disturbance term. Mathematically, the estimation is explained as the following equations:

$$
\begin{aligned}
& \Delta P_{t}=\theta_{0 t}+\sum_{i=1}^{k-1} \tau_{0 i} \Delta \mathrm{P}_{t-1}+\eta_{0 t} \\
& P_{t-k}=\theta_{1 t}+\sum_{i=1}^{k-1} \tau_{1 i} \tau_{1 i} \Delta P_{t-1}+\eta 1 t
\end{aligned}
$$

where Pt is a vector of the ordered prices, $n t$ is the dimensional vector random errors, $\theta \mathrm{t}$ is the intercept, while $\tau$ is the matrices of the estimated coefficient.

There are two test statistics applied in Johansen test, i) trace statistics and ii) maximum eigenvalue test. Trace statistics is used to analyze the amount of rcointegrating vectors in $\mathrm{Pt}$ while maximum eigenvalue is used to determine the exact cointegrating vectors in Pt. In the Johansen test, the number of cointegrated relation is counted by the amount of rejected null hypothesis. The null hypothesis is that there is no cointegration in $\mathrm{r}=\mathrm{k}$. Rejected null hypothesis means that there is cointegration relation as much as the amount of $\mathrm{k}$.

\section{Estimates the Error Correction Model}

Cointegrated variables indicate that (i.e., if the null hypothesis of no cointegration relationship cannot be accepted) the residuals from the equilibrium regression can be used to estimate the error correction model. If $\{\mathrm{yt}\}$ and $\{\mathrm{zt}\}$ are CI $(1,1)$, the error correction form of the variables is as follows:

$$
\begin{aligned}
& \Delta y_{t}=\alpha_{1}+\alpha_{y}\left[y_{t-1}-\beta_{1} z_{t-1}\right]+ \\
& \sum_{i=1} \alpha_{11}(i) \Delta y_{t-i}+\sum_{i=1} \alpha_{12}(i) \Delta z_{t-i}+ \\
& \varepsilon_{y t} \\
& \Delta z_{t}=\alpha_{2}+\alpha_{z}\left[y_{t-1}-\beta_{1} z_{t-1}\right]+ \\
& \sum_{i=1} \alpha_{21}(i) \Delta y_{t-i}+\sum_{i=1} \alpha_{22}(i) \Delta z_{t-i}+ \\
& \varepsilon_{z t}
\end{aligned}
$$

where $\beta_{-} 1$ is the parameter of the cointegrating vector, $\varepsilon \_y t$ and $\varepsilon \_z t$ are the white noise disturbances and all the $\alpha$ are parameters (Enders 2010).

Engel and Granger (1987) proposed the magnitude of residual $\mathrm{e}^{\wedge}(\mathrm{t}-1)$ as the deviation from the long-run equilibrium in period ( $\mathrm{t}-1)$. Using $\mathrm{e}^{\wedge}(\mathrm{t}-1)$ as an estimation of the expression [y_(t-1)- $\beta_{-} 1$ $\mathrm{z}$ ( $(\mathrm{t}-1)$ ], the error correction model could be transformed as:

$$
\begin{aligned}
& \Delta y_{t}=\alpha_{1}+\alpha_{y} \hat{e}_{t-1}+\sum_{i=1} \alpha_{11}(i) \Delta y_{t-i}+ \\
& \sum_{i=1} \alpha_{12}(i) \Delta z_{t-i}+\varepsilon_{y t} \\
& \Delta z_{t}=\alpha_{2}+\alpha_{z} \hat{e}_{t-1}+\sum_{i=1} \alpha_{21}(i) \Delta y_{t-i}+ \\
& \sum_{i=1} \alpha_{22}(i) \Delta z_{t-i}+\varepsilon_{z t}
\end{aligned}
$$

\section{NEW ZEALAND'S MILK INDUSTRY}

New Zealand is a country with a relatively high dependency on the international market. More than a half of the country's products are being exported, especially for agricultural products (OECD, 2013). New Zealand has a powerful comparative advantage in the 
agricultural sector (Rae, 2003). Ministry for Primary Industry of New Zealand (2014) has reported that the agricultural sector together with the food and forestry sector has successfully generated $70 \%$ of New Zealand's earnings from export. The sectors also contribute about $12 \%$ of the national Gross Domestic Product (GDP).

New Zealand has built a competitive system in their agricultural sector. Dairy sector is one of the evidence of its success history. New Zealand is the world's largest dairy and sheep meats exporter worldwide (Ministry of Primary Industry of New Zealand, 2014). Dairy sector has contributed the largest share from this country's total export. Dairy sector also significantly improves the country's economy. New Zealand holds 35\% market share of the world dairy products. At 2012, the total dairy products worth for US\$ 6,24 million with production volume reached 2 million tonnes.

IUF (2011) reported that the success story behind New Zealand's dairy sector is supported by some key strategies. First, New Zealand has a comparative advantage due to its favourable endowment of natural resources for grass and field. The second is the existence of the competitive processing industry. There are seven dairy processing companies in the New Zealand's dairy industry. Fonterra Cooperative Group is the biggest. It supplies about $90 \%$ of the total production, and about $7 \%$ is contributed through the Gross Domestic Product. Fonterra also controls about $40 \%$ share in the local market (IUF, 2011). The third factor is the strategy of marketing and distribution around the world. New
Zealand has a unique marketing strategy, therefore the country is capable of managing the market and consumers worldwide in a more sustainable way.

The most exported dairy products from New Zealand is mainly in a form of whole milk powder. Statistic data showed that the export value of whole milk powder reached $48,7 \%$ of the New Zealand's total dairy export in 2013. The largest importer of New Zealand's dairy product is China, which imports almost $35 \%$ of New Zealand's dairy exports. Specifically, China imports milk in a solid form, whey and also butter. However, New Zealand also imports some of their dairy needs, which basically are originated from the USA and the Australia.

New Zealand government does not give any specific subsidies for the dairy sector. Initially, policy support through subsidies from the government even triggers an overproduction and left environmental degradation impact on the domestic sector. Furthermore, those subsidies which covered approximately $30 \%$ of the full production cost also led to rising prices on land costs. However, later in 2001, it was reported that by suspending the subsidies, it even gave a good impact to the agriculture (IUF, 2011). However, been dominated by several big companies, New Zealand's dairy industry become one of the best examples for a vertically integrated market and supply chain. Fonterra, Tatua and Westland are collecting the milk from their local farmers and produce a high quality of milk product. 
Currently, New Zealand is focusing on some trade policies. New Zealand specifically concerns on revising innovation policies. The country is trying to boost productivity, economic growth and sustainability in forestry and food sector through research and investment activities. Besides, New Zealand also concerns about the environmental issue. The country ensures their agricultural production will not give any negative impact which causing environmental degradation. GHG emissions should always be reported within the New Zealand's trading schemes. New Zealand also involved in several trade agreements. The most updated is the ASEAN Australia and New Zealand Free Trade Agreement (AANZFTA) (OECD, 2013).

\section{PRICE TRANSMISSION ANALYSIS OF SKIM MILK POWDER}

The international price transmission between the price of exported Skim Milk Powder by New Zealand to Indonesia and the price of imported Skim Milk Powder by Indonesia from New Zealand is processed through the steps which have been explained in the method section. This analysis examines whether different market of Skim Milk Powder (New Zealand and Indonesia) indicates an integrated relationship or not. New Zealand as an exporter is expected to have more power than Indonesia, especially in price determination process. The approach of price transmission analysis can be used to analyze the existence of market power run by New Zealand to Indonesia. Further, the analysis also reflects the efficiency of the applied free trade agreement between Indonesia and New Zealand.

\section{Unit Root Test}

The first step of measuring price transmission is to check the stationarity of the data. Stationarity is an important aspect in time series analysis since a nonstationary data can lead the results into a bias estimation. Stationarity test mainly performs by checking the existence of a unit root in the variables. In that case, Augmented Dickey Fuller (ADF) test was applied to check the unit root. There are many approaches to carry out unit root test (Maddala and Kim, 1998). However, ADF test which initially introduced by Dickey and Fuller (1979) is widely used in many price transmission studies.

Basically, there are some important steps that should be considered before testing the unit root. First is to set the maximum lags, second is to choose the lags criterion, and finally the third is to determine the assumption of an intercept, trend or both of them do exist in the observation. This study assumes that maximum applied lags are 13 lags, which is generated from the Schwert Criteria (Schwert, 1989):

$1_{12}=12 \times\left(\frac{T}{100}\right)^{1 / 4}$

by assuming $\mathrm{T}$ is the total observations (163 observations). Lags criteria selection is another important issue to be considered, different results will appear when different lags conducted. There are three different lag criteria which commonly used on lags determinations, 
there are Akaike Infor-mation Criterion (AIC), Bayesian Infor-mation Criterion (BIC) and Hana Quin-Criterion (HQC). AIC is used in this study as a basis in determining the lag. Table 3 shows the results of unit root tests for all variables.

On the data level, both of the Exported Milk Price's t-statistics $(1,2418)$ and Imported Milk Price's statistics $(0,2768)$ show a higher result than the critical value. This means, on the level, both of these variables are accepting the null hypothesis of not stationary. In the case of variables are not stationary in level, further calculation might causes a spurious regression which resulting a meaningless interpretation. However, if the variables are indicated stationary on the first difference and further they are proven to have a cointegration relationship, these variables might have a meaningful interpretation on the long run, even in the short run they are not stationary.

Therefore, further check on the stationarity is needed. Table 3 shows also the result of unit root test for the first difference data. The result shows that together all the variables are rejecting the null hypothesis in their first difference. Variable Exported Milk Price and Imported Milk Price are resulted tstatistics $-4,5708$ and $-6,3218$, respecttively. Both of the results show a lower value than the critical value. It means that all variables; Exported Milk Price and Imported Milk Price are stationary at the first difference or I (1). As explained previously in the method section, nonstationary data can be processed and expected to be unbiased as long as they are confirmed stationary at the first difference. Moreover, since all variables are stationary in their first difference and at the same time are also in the same ordo, cointegration test between those variables could be conducted.

\section{Cointegration Test}

Cointegration test is simply testing the possibility of the long run relationship between non-stationary variables. If some stationary variables are not stationary in level, but stationary in their first difference, they might have a dynamic price behavior which moves along (cointegrated) in the long run. In this study, cointegration test was performed by using the Johansen test. The results are shown in Table 4.

Cointegration test performed by Johansen test allowed us to process cases with multivariate variables. Based on the lags criteria, maximum lag number and optimum lags number, the cointegration test on Exported Milk Price and Imported Milk Price variables indicate a cointegration relationship. The $\mathrm{p}$-value in the rank $0 \quad(0,0053)$ directed to the conclusion of accepting null cointegration or the conclusion of no cointegration relationship in the long run. However, on the rank 1 , the calculation is resulting $\mathrm{p}$-value which is larger than 0,1 $(0,4393)$, which leads to a conclusion of rejecting the hypothesis of no cointegration and therefore accepting the hypothesis of there is at least one cointegration relationship between variable Exported Milk Price and Imported Milk Price variable. 


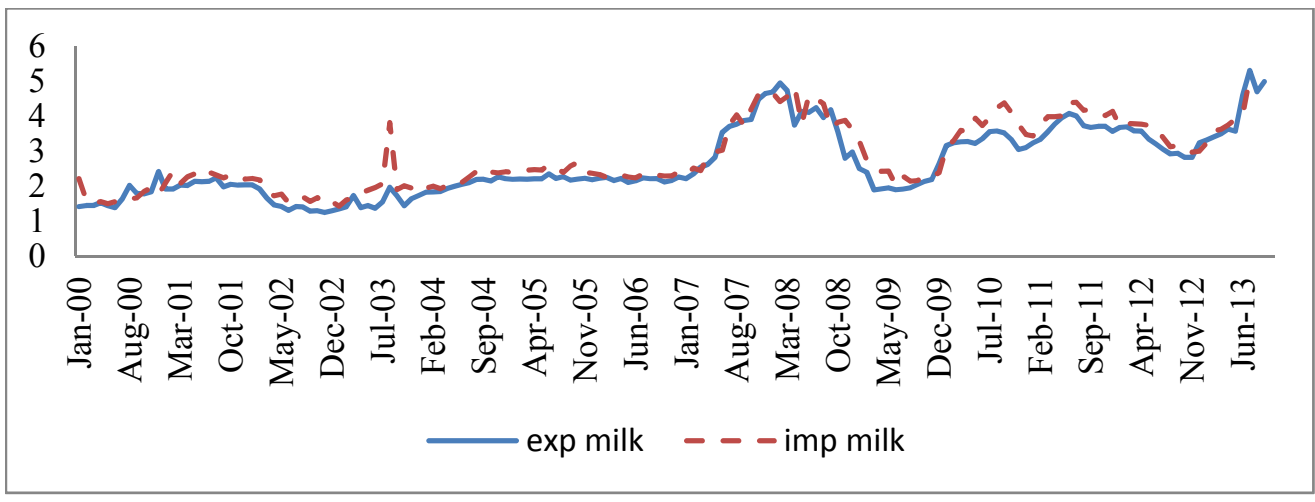

Source: Ministry of Industry (2013)

Figure 4. All Price Data in Logarithm

Table 4. Cointegration Test Result Using Johansen Test

\begin{tabular}{lccc}
\hline \multirow{2}{*}{ Variable } & \multicolumn{3}{c}{ Cointegration Result (P-Value) } \\
\cline { 2 - 4 } & Optimum Lags & Rank (r) & Johannsen \\
\hline Exported Milk Price & 5 & 0 & 0.0053 \\
Imported Milk Price & & 1 & 0.4393 \\
\hline Lags criteria: Akaike Information Criterion (AIC) & & \\
Max Lags: 13 & & & \\
Test with Constant & & & \\
Processed by using Jmulti & &
\end{tabular}

\section{Price Transmission Model}

To examine the relation between the exported milk price and the imported milk price, the error correction model was performed. The model was constructed by considering intercept in the equation. Akaike Information Criterion (AIC) is chosen. Based on the lag criteria, the AIC calculation is suggested to apply five lags as the optimal lags in the model. Since the Johansen test leads to the result of one cointegration relationship between the Exported Milk Price variable and Imported Milk Price variable, therefore the VEC model is applied by considering one cointegration relationship between these variables. The result of VEC Model is shown in Table 5.

Table 5 presents the estimated coefficient for the long run and the short run relationship between the exported Skim Milk Powder price from New Zealand (indicated by 'expmilk' notation) with imported Skim Milk Powder price in Indonesia (indicated by 'impmilk' notation). As both variables are proven to be stationary at their first difference and have one cointegrated relationship in the long run, therefore the Error Correction Model could be performed.

First of all, from Table 5 one can be analyzed from the long run equation is that the intercept and the coefficient of imported Skim Milk Powder are 
Table 5. Error Correction Model of Skim Milk Powder in New Zealand and Indonesia

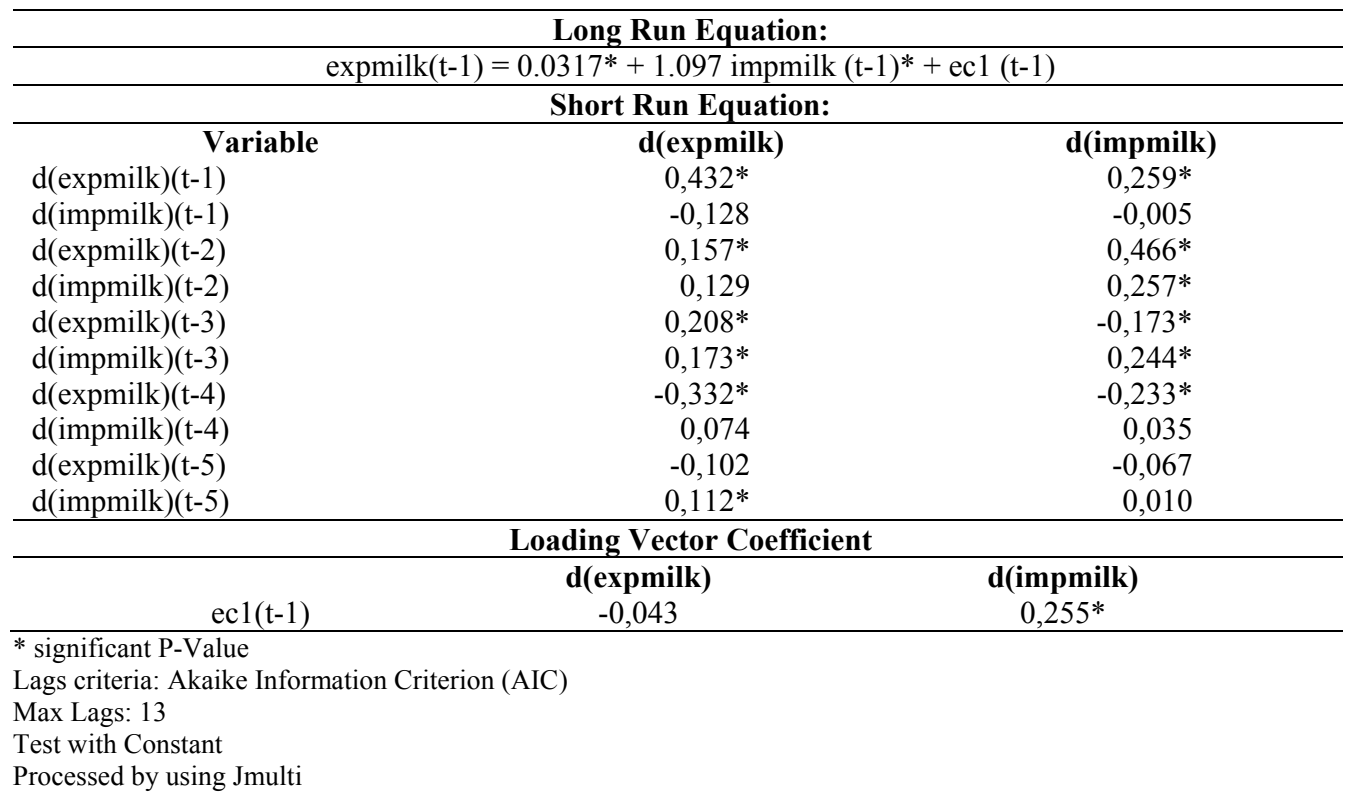

significant. This means that imported Skim Milk Powder's price is being influenced by the exported price in New Zealand. Therefore, it can be concluded that every $10 \%$ increase of exported Skim Milk Powder price in New Zealand might influence the imported Skim Milk Price in Indonesia in the same direction for about $10,97 \%$ in the long run. The estimation shows that in the long run, import price is reflecting a full price transmission of the New Zealand's export prices. This means, changes in New Zealand are fully transmitted to Indonesia. The better prices are being transmitted, therefore the better market integration between both countries occurred.

In a short run, exported price in New Zealand is expected to be more influenced by its previous price (the previous 14 month) and less by the previous imported milk price in Indonesia (the previous 3 and 5 months). Meanwhile, the imported milk price is indicated to be more influenced by the previous exported milk price (especially, the 1-4 month earlier) than by its imported milk prices (the 2 and 3 months earlier). The short run equation for import milk shows that the export milk price relatively has a larger influence to the Indonesia's import milk price. On the other hand, the imported milk prices are showing less power to the export prices. The import price does matter to the export price, but the magnitude is relatively small.

Further, Table 5 is also shows the result of coefficient of error correction or ec (t-1) which explains the speed of adjustment of the changes. The ec $(\mathrm{t}-1)$ is reflecting how fast changes in price will be brought back into the equilibrium in the long run. From the equation, we could 
see that there is only one significant error correction term, which appears in the imported Skim Milk Powder prices variable. This means, whenever it occurs disequilibrium in the long run, or whenever there are changes in one country, it will be only the imported milk prices in Indonesia which will adjusting to the changes, until the price reach the equilibrium again. The same condition will not occur if imported milk price changes, the exported Skim Milk Powder price in New Zealand will not react to the disequilibrium. The loading vector coefficient shows that the imported price variable will adjust to disequilibrium for about 0,255 units of time. The results above is clearly reflecting the condition which mentioned in the previous section. In the case of export and import milk, specifically Skim Milk Powder, Indonesia as a net importer is proven to have an integration with its partner country, New Zealand. The full price transmission and market integration, which is reflected on the long run coefficient could be an indication of the effective free trade agreement which committed by these two countries. Further, the loading vector coefficient explained deeper analysis in regard to the trade relationship between these countries. The significant loading vector coefficient in imported Skim Milk Powder price variable provides the evidence of New Zealand's power in the milk market. Thus, New Zealand's milk prices will not be affected by any changes of the small importer country in this case, Indonesia.
Statistically, New Zealand contributes about 30 percent of total Indonesia's milk need (ITC, 2014). In Skim Milk Powder, New Zealand has became an important supplier for Indonesia's dairy companies through $33,6 \%$ export supply in the year 2012 (ITC, 2014). Meanwhile, Indonesia's import is only around $4,1 \%$ of the New Zealand's total export. Therefore, the tendency of import milk dependence from Indonesia to New Zealand might expect the milk price determination, and higher market power in New Zealand.

Finally, by the condition of Indonesia's milk import dependency, the government, companies and other policy makers should concern some alternative strategies. Based on this situation, some policies could be applied to minimize the price risks in Skim Milk Powder trade: i) the milk importers and milk processing companies should concern the budget buffer to overcome a sudden shock in international milk prices, ii) search for other alternative milk suppliers and iii) concern the future trade system to be as the transaction method.

\section{CONCLUSION AND RECOMMENDATION}

New Zealand is a country with a high dependency on international trade, since it exports on agricultural product is also high. New Zealand's agricultural sector and forestry generate the highest export earnings, it reaches almost $70 \%$ of the total New Zealand's income from the export activity. Through the agricultural business, the Gross Domestic Product 
(GDP) of this country has also been contributed for about $12 \%$.

The New Zealand's dairy sector becomes one of the primary sector. This sector is now dominating the world's market share for about $35 \%$. Nowadays, New Zealand is the largest exporter of dairy and sheep meats worldwide. New Zealand applies the best vertical integration of the dairy supply chain and market. Through some capital companies, New Zealand builds a strong dairy system which connected the industry with the farmers and producing a high quality dairy products.

Today, the New Zealand's agricultural policy is stressing on the productivity, growth and sustainability. The government supports the sector through the intensive research and development activities. The environmental issues are being largely concerned, companies are directed to run the business without causing environmental degradation. Internationally, New Zealand is collaborating with some partner countries to enhance their trade relations. The ASEAN Australia, New Zealand Free Trade Agreement (AANZFTA), is an agreement which bounds Indonesia as one of the ASEAN country with New Zealand.

Specifically, in the Skim Milk Powder, the test of price transmission analysis resulting an evidence of market integration between New Zealand and Indonesia. The Johansen test resulting one cointegration relationship between these two markets. Thus, any shock in the New Zealand market might affect the Indonesian market, vice versa. If there are changes in the New Zealand's price, the domestic importer in Indonesia should anticipate this dynamic condition. The related policy maker should consider some alternative strategies to overcome the situation.

Moreover, the Error Correction Model indicates an interrelationship between the exported Skim Milk Price with the imported Skim Milk Price. The coefficient variable on the imported Skim Milk Powder is detected a higher magnitude of transmission (10.97\%) in comparison to the coefficient variable of exported Skim Milk Powder in New Zealand $(9.12 \%)$ for every $10 \%$ changes in one market. However, based on those coefficient variable results, both prices are indicated to be fully transmitted in magnitude.

In the short run, exported Skim Milk Powder is influenced by its previous price more than the previous imported prices. However, the imported Skim Milk Powder's price are more influenced by its previous price than the exported prices. Further, the loading vector coefficient indicates a different speed and price response between these two prices. The imported Skim Milk Powder Price in Indonesia is proven to be influenced by the New Zealand's price, but not for the exported Skim Milk Powder price in New Zealand which is not influenced by the Indonesian price. Imported prices are also indicated to have a higher speed in responding disequilibrium in the long run.

At last, by the condition of Indonesia's milk import dependency, the government, companies and other policy 
makers should concern some alternative strategies. Based on this situation, some policies could be applied to minimize the risks: i) concern the company's budget buffer, ii) search for other alternative milk suppliers and iii) concern the future trade system to be applied in the company.

\section{REFERENCES}

Abdulai Awudu. 2006. Spatial Integration and Price Transmission in Agricultural Commodity Markets in Sub-Saharan. Agricultural Commodity Markets and Trade: New Approaches to Analyzing Market Structure and Instability. Edited by Alexander Sarris and David Hallam. FAO. Edward Elgar Publishing Limited, United Kingdom.

Asnawi Yudha Heryawan. 2012. Strategi Pengembangan Klaster Industri Susu. [Report]. Documented in: Rapat Koordinasi Forum Komunikasi Persusuan Jawa Tengah, Semarang on June 28th 2012. Not Published.

Baga Lukman M., Yanuar Rahmat. 2009. Analisis Kelayakan Model Klaster Industri Susu Sapi Perah di Indonesia (Studi Kasus: Jawa Barat dan Jawa Tengah). [Research Proposal].Bogor: Institut Pertanian Bogor. Not Published.

Dickey David A. and Fuller W. A. 1979. Distribution of the Estimators for Autoregressive Time Series with a Unit Root. Journal of the American Statistical Association, Volume 74, Issue 366. Page 427-431.
[Ditjennak] Direktorat Jenderal Peternakan. 2010. Statistik Peternakan 2010. Jakarta: Kementrian Pertanian Republik Indonesia.

Enders Walter. 2010. Applied Econometric Times Series. New York: John Wiley and Sons, Inc.

Engle Robert F. and Granger C. W. J. 1987. Co-Integration and Error Correction: Representation, Estimation and Testing. Econometrica, Volume 55, Issue 2 (Mar., 1987), page 251-276.

Fackler Paul L. and Goodwin K. 2001. Spatial Price Analysis. Handbook of Agricultural Economics, Volume 1, Edited by B. Gardner and G. Rausser. Department of Agricultural a--nd Resource Economics, North Carolina State University, Raleigh, NC. Elsevier Science B.V.

[ITC] International Trade Center. 2014. Trade Statistics for International Business Development (Trademap). January 2014 from $<$ www.trademap.org $>$.

[IUF] International Union of Food. 2011. New Zealand Dairy Industry. IUF Dairy Division.

Marshall, A. 1890. Principles of Economics, 8th Edition. Macmillan Company. New York.

Meyer Jochen and Taubadel Stephan con Cramon. 2002. Asymmetric Price Transmission: A Survey. Journal of Agricultural Economics Volume 55, Number 3, pages 581 611. 
Ministry of Industry. 2009. Peta Panduan (Road Map) Pengembangan Klaster Industri Prioritas Industri Berbasis Agro Tahun 2010-2012. Jakarta: Kementrian Perindustrian Republik Indonesia.

\section{Kementrian}

Perindustrian Republik Indonesia. December 2013 taken from http://www.kemenperin.go.id/.

Ministry of Trade. 2013. Sistem Pemantauan Pasar Kebutuhan Pokok (SP2KP), taken from -http://ews.kemendag.go.id/.

. 2014. Free Trade Agreement. Kementrian Perdagangan Republik Indonesia on http://www.MinistrY of Trade.go.id/id/faq\#h-1. Accessed on January 2014.Ministry of Primary Industry of New Zealand. 2014. Agriculture and the New Zealand Economy. 28 February 2014 from http://www.mpi.govt.nz/agricultur e.

[OECD] Organization for Economic Cooperation and Development. 2013. Agricultural Policy Monitoring and Evaluation 2013: OECD Countries and Emerging Economies. OECD.

Rae Allan. 2013. New Zealand Agriculture. Paper prepared for Henan Agricultural University. Massey University, New Zealand.
Rapsomanikis George, Hallam David, Conforti Pierro. 2003. Market Integration and Price Transmission in Selected Food and Cash Crop Markets of Developing Countries: Review and Applications. Agricultural Commodity Markets and Trade: New Approaches to Analyzing Market Structure and Instability. Edited by Alexander Sarris and David Hallam. FAO Edward Elgar Publishing Limited, United Kingdom.

Ravallion Martin. 1986. Testing Market Integration. American Journal of Agricultural Economics, Volume 68, No. 1, pages 102-109. Oxford University Press, United Kingdom.

Schwert G. William. 1989. Tests for Unit Roots: A Monte Carlo Investigation. Journal of Business and Economic Statistics, Volume 7, No.2.

Tomek William G. and Robinson Kenneth L. 1990. Agricultural Product Prices. Cornell University Press, New York.

Verbeek Marno. 2012. A Guide to Modern Econometrics. Fourth Edition. John Wiley and Sons, Ltd. United Kingdom. 
Venty Fitriany Nurunisa, Bonar Marulitua Sinaga, Ratna Winandi and Bernhard Brümmer 